\title{
MODERN SHI'I ISLAM AND THE NARRATIVE OF SOCIAL POWER: THE VIEWS OF MUHAMMAD HUSAYN FADLALLAH
}

\author{
Bianka SPEIDL \\ MTA-SZTE Research Group for the Study of Religious Culture \\ Egyetem u. 2, H-6722 Szeged, Hungary \\ E-mail: biaspeidl@gmail.com
}

\begin{abstract}
In modern Shi'i Islam, power constitutes a major concern for thinkers and movements alike. Above all, Muhammad Husayn Fadlallah stands as the most systematic Shi'i thinker who produced an Islamic theory of power. The present article analyses Fadlallah's concept of social power. In Islam and the Logic of Power (al-Islam wa-mantiq al-quwwa), he emphasised the importance of social solidarity, justice, and the obligation of "commanding right and forbidding wrong" as a means to create the ideal society. For him, this social model has a reciprocal relation to social power. Muhammad Husayn Fadlallah tells the tale of two societies: the weak and the strong, arguing that beliefs, unity and values determine the power of a community. He claims that the strong society is best illustrated by the first Islamic community. He confronts it with the weak society which lacks unity and solidarity - echoing to a great extent contemporary Lebanon. Fadlallah's social theory - embedded in his theology of power - transforms spiritual power into a collective deployment of action. He draws on a wide range of elements (Sunni, Shi'i and Marxist) to create a coherent system of power in which social power is a mediator between the ideology of power and its political manifestation.
\end{abstract}

Keywords: Shi'ism, empowerment, mobilisation, solidarity, organic unity, equilibrium, shari'a, faith

\section{INTRODUCTION}

Muhammad Husayn Fadlallah (1935-2010) was born in Iraq in a family of Lebanese origin. After concluding his studies in Najaf, the Iraqi centre of Shi' i religious sciences, in 1966 he moved to Lebanon and soon became the most prominent Shi'i jurist in the country. He founded "The Higher Islamic Legal Institute", in which several later prominent religious scholars and political activists - affiliated with the Hezbollah - studied. By the early 1980s, he gradually became the leading religious figure in the Shi'i community. His book, Islam and the Logic of Power, written in 1976 amidst the devastating bombardments of the Lebanese civil war offers the Shi'i community a narrative of social power in which social values, relations and collective action are mobilised to build a grassroot 
Shi'i social movement. Much of Fadlallah's social ideas were implemented in the social programme of Hezbollah.

In the following, I pay close attention to Fadlallah's concept of social empowerment in relation to four contexts. First, I analyze his views with regard to the Shi' $i$ context. Second, I highlight his binary understanding of social weakness and power. Third, I emphasize Fadlallah's social functionalism, discussing his debt to Durkheim. Finally, it will be shown that his social thought found an echo in the Shi'i social activism.

\section{SOCIAL THOUGHT IN MODERN SHI'ISM}

Responding to social challenges from an Islamic perspective was a concern to the most influential thinkers of Shi' ism in the last century. Above all, Ali Shari'ati and Muhammad Baqir al-Sadr are considered as the major Shi'i social theorists. Their primary aim was to define the Islamic social philosophy and to differentiate it from the Western intellectual tradition. Both al-Sadr and Shari'ati aimed to provide Islamic answers to the most dominant and appealing Western ideologies such as Marxism and capitalism. ${ }^{1}$ In particular, Marxism was a direct rival to Shi' ism in Iran and Iraq in the 1960s with its revolutionary call to the liberation of the oppressed. Due the great appeal of Marxist thought to the young and impoverished Shi'a, religious scholars and intellectuals had to craft a persuasive social thought in order to cope with the Marxist dominance in social theory. This meant the need to adopt some crucial Marxist concepts by reinterpreting the religious doctrines and "Islamising" its revolutionary agenda.

In Iran, Shari'ati set out to rediscover the Qur'an in the light of Marxism and existentialism, and presented revolutionary ideas by applying religious symbolism. He transformed Shi'ism into a theology of liberation. His ideas about society are compiled in a volume entitled On the Sociology of Islam that consists of his lectures given in 1968 specifically dedicated to the various aspects of his social thought. In Iraq, Muhammad Baqir al-Sadr wrote one book specifically dedicated to the analysis of Islamic society: Contemporary Man and the Social Problem, but other volumes such as al-Madrasa al-Qur'aniya or the posthumously published Our Society also contain his essays and lectures on social issues.

In Lebanon, Fadlallah had to transform the theology of weakness prevalent among the Lebanese Shi'a into the theology of force. Therefore, he reconfigured religion by selecting and emphasizing the elements of strength and discarding elements of weakness. He was concerned with the social structure and social values from the perspective of their relation to the quality and quantity of social strength they produce. Fadlallah labelled any interpretation as destructive that opposed the understanding of Islam in general and Shi' ism in particular as the only solid and legitimate base for social empowerment.

His focus - all through the book - lies on understanding power. He formulated his concept based on the Shi'i dissatisfaction with their social conditions. Also, he was aware that several secular, revolutionary political factions tried to attract and recruit the Shi'a.

${ }^{1}$ Several studies dealt with the social thought of Shari'ati and al-Sadr. For example, see: Alatas 1999: 113-129; Ibrahim 1997; Aknavi 1988: 404-431; Yadegari 1984: 53-59; Dabla 1983: 277-282; AkhaVi 1983: $125-144$. 
This fact prompted him to formulate his social concept as a prelude and prerequisite for activism and political change. By the late 1960s, the social status of the Shi'a became a matter on which the survival of the community depended. In Islam and the Logic of Power, Fadlallah tells the tale of two societies: the weak and the strong. He argues that beliefs, unity and values determine the power of a community. Fadlallah claims that the strong society is best illustrated by the first Islamic community. He confronts it with the weak society which lacks unity and solidarity - echoing to a great extent contemporary Lebanon.

\section{FADLALLAH'S SOCIAL THEORY}

In Fadlallah's interpretation, society is the sphere in which power is embodied, the first concrete empowerment of the Shi'i community is realised, and the continuity of the Islamic message is maintained. Social power comprises social values, relations and collective action. It allows, as a first stage, the building of bottom up power in contrast with bottom down empowerment through politics. This mechanism fits better to the paradigm of gradual transformation as it engenders power in the various social structures - such as family, education, economy -, rendering it sustainable. It helps to deracinate quietism and passivity at their roots and makes the social autonomy of the Shi'i community possible. Fadlallah was aware of the importance of social power to provide the Lebanese Shi'a with its own social assets. He sought to give it social freedom (from want, poverty and misery) and confidence before it has access to political power.

Fadlallah starts his study of social strength by stating that there is no specific and direct analysis of social strength in either the Qur'an or in the reported traditions. Therefore he sets out to construe a comprehensive essay on this issue by embracing its intellectual, behavioral and legal aspects. The chapter on "Social power" comes after spiritual power and precedes a series of chapters on political power. Thus in the book it provides a passage from individual power - as put forward in his concept of theology and spirituality - towards attaining political power through social mobilisation. Therefore, it can be said that social power is the bridge between belief and revolution.

Fadlallah derives the base principles of the social formula and social strength from the Qur'an, however, in many cases he refers to the Prophetic and Twelver Shi'i traditions as well. His argument on the interrelatedness of salvation and the social formula, the characterization of the first Muslim community, the description of weak society, the link between social cohesion and personal responsibility, and the importance of unity are substantiated by exclusively Qur'anic passages as the primary source regarding the first Muslim community and the sacred common ground for Sunnis and Shi'ites.

\section{WEAK SOCIETY: FADLALLAH'S SOCIAL CRITICISM}

In Fadlallah's perception, a weak society is the one that lacks social coherence. The lack of shared values, commitments and responsibilities exercise a centrifugal power that leads to its destruction. He illustrates weak society by the Jewish community of the Prophet's time. The Jews of Medina 
had conflicting personal interests that made each faction or even each person an independent entity whose interests and goals conflicted with those of the others in the community... [The] difference in feelings, inclinations and orientations that turns into differing plans, actions, stances [...] is in fact internal fragmentation that transforms into an external one. ${ }^{2}$

In Fadlallah's thought, weakness is not an attribute, rather it is a condition in which the community lacks the strategic power needed to maintain its integrity, exercise its interests and spread its values. Fadlallah considers attitudes based on individual inclinations and aspirations as by-products of human civilisation. Decline occurs when the individual's attachment to society is weakened and ego-centrism prevails. Such society becomes defenseless and paralyzed. The abandonment of supreme values that cement commitment and loyalty in the individual towards the community obliterate solidarity and create a system of injustice and inequality. Religion in general and Islam in particular provides such values and guides their implementation. ${ }^{3}$

In Islam and the Logic of Power, manifestations of weakness are explored in three major aspects of social life: the intellectual, the emotional, and the practical domains. At the intellectual level, Fadlallah criticizes certain groups whose views pose a direct threat to social unity. He identifies three of them as particularly harmful: the luxury elite, which dominates and exploits others; the dividing elite of religious scholars and politicians, who seek to divide society so that they can exploit it to promote their own interests; and the heretics and the non-believers, who attack the belief of the Muslim society and thus shake the principles on which its system of values is based. ${ }^{4}$

Second, Fadlallah depicts the emotional roots of weakness. He considers feelings based on kinship and not on merit as a threat because they turn the absolute religious values into contingent ideas and substitute faith with human considerations. Serving the interests and contributing to the mission of the community enjoys priority over any personal concerns or bonds. Only if Islamic values determine the thoughts and actions of the people, can the society be protected from individualist and destructive trends. ${ }^{5}$

At the practical level, a weak society is characterized by corruption in all sectors of society. The only way to eradicate the roots of this corruption is to fulfil the duty of "forbidding wrong", rather than leaving the responsibility of dealing with it to the official authority once it becomes a habit. ${ }^{6}$ There is a natural causality, through which passivity and negligence not only weaken a society but they eliminate any chances for re-empowering it.

Fadlallah, the Shi'i jurist, extensively quotes Sunni sources to emphasise the responsibility of the governed for their just governance and to eliminate deviation from among their ranks. On the one hand, highlighting the requirement of unity demands a discourse

\footnotetext{
${ }^{2}$ Fadlallah 1985: 121.

${ }^{3}$ FadLallah 1985: 122.

${ }^{4}$ FadLALlah 1985: 127-132.

${ }^{5}$ Fadlallah 1985: 139-141.

${ }^{6}$ Fadlallah 1985: 152-154.
} 
that embodies this value and makes it tangible for the reader. On the other hand, it reflects the author's wish to address the broader possible audience and shows his concern about the Sunni-Shi'i divide in the Muslim community.

\section{FADLALLAH'S VISION OF A STRONG SOCIETY}

In contrast to the model of weak society - the Jewish community of Medina - Muhammad's community stands as the perfect ideal of a strong "society". The first Muslim society, as Fadlallah puts it, is a living, universal model which should be followed in the present and the future. He understands social strength as rooted in the interaction among its members. ${ }^{7}$ He offers a detailed analysis of how compassion, unity and common goals are embodied in social relations and practices, and eventually create indestructible social bonds. For Fadlallah

[t]he term social strength refers to the strength that communities possess through unity the practical aspects of which are manifested in cohesion and mutual bonds among its members based on shared thought, feelings, and action towards a common goal. ${ }^{8}$

Strength in this sense is rooted in and secured by unity which in turn is constructed by the interplay of three major factors: cohesion, ideology, and joint effort. Fadlallah sets to show the elements of this utopia in three areas which aim to replace the elements of weakness: the bond of belief-thought-feeling, social values, and organic unity.

\subsection{THE SOCIETY OF BELIEVERS: BONDS OF BELIEF, THOUGHT AND FEELING}

Fadlallah is convinced of the interrelatedness of the social and spiritual aspects of human life. ${ }^{9}$ He asserts that God's mercy towards mankind must be manifested in human relations. ${ }^{10}$ Thus, in a community of believers faith determines values and human interactions. Thus the intellectual, emotional, and practical aspects are independent of material circumstances. ${ }^{11}$ In Fadlallah's view, religious obligations function "as norms that govern relations and defines behaviour constitute the unifying element that reconcile the diverse components of a community". ${ }^{2}$ In this context faith has tangible function: it creates reality by shaping the consciousness of the individuals and, consequently, the norms of the community. As such, it secures order based on shared values and conventions. Religious

\footnotetext{
${ }^{7}$ Fadlallah 1985: 110.

${ }^{8}$ FadLallah 1985: 110.

${ }^{9}$ FADLALlah 1985: 117.

${ }^{10}$ Fadlallah 1985: 115.

${ }^{11}$ FadLallah 1985: 116.

${ }^{12}$ Fadlallah 1985: 122.
} 
institutions and practices reflect, maintain, and create cohesion among those who participate in them. ${ }^{13}$

Fadlallah argues that compassion is a general attitude based on the consideration of objective circumstances. ${ }^{14}$ By claiming that feelings and emotions are results of a personal internal process controlled by ideological convictions, ${ }^{15}$ Fadlallah's aim is to pave a logical sequence that leads from compassion through social cohesion towards social strength. ${ }^{16}$

Fadlallah's ideas regarding intellectual freedom carry considerable ambiguity. On the one hand, for him, the intellectual bases of social unity, the doctrinal beliefs as well as the general principles of life must be derived exclusively from the Qur'anic revelation and must be preserved without any concessions to ambiguity or dualism. ${ }^{17}$ Therefore propagating a view that challenges or attacks the ideological foundations of the society is forbidden. On the other hand, he accepts freedom in making an individual choice in ideological issues, and considers conducting dialogue with those who have differing views as both a right and a duty. ${ }^{18}$ However, Fadlallah explicitly stated that dialogue and co-operation in the final count were only tools to defend and spread the Islamic doctrine. ${ }^{19}$

\subsection{SOCIAL VALUES: JUSTICE, SOCIAL RESPONSIBILITY AND SOLIDARITY}

Fadlallah maintains that the Qur'an is explicit in declaring practical action as the only real proof of the sincerity of belief. ${ }^{20}$ Man's mission is to realize Divine justice on Earth, as the ultimate goal of Islam. Justice creates equilibrium in the society, a context within which Man is able to use his full capacities as God's vice-regent. Fadlallah's understanding of "justice" is based on the revelation. In individual life, justice is embodied in actions corresponding to the divine decrees that assure the ethical dimension of life, and thus serve the ultimate interests of human beings. ${ }^{21}$ Applied justice is the governance that bases decisions on the revealed distinction between righteousness and deviation. ${ }^{22}$

Fadlallah argues that in Islam, social strength is built upon social cohesion through general and individual responsibilities. ${ }^{23}$ This implies firmness and rigour against those whose ideas or actions weaken society from inside. Thus an internal cooperation based on strength and violence is indispensable against those internal and external elements that promote disintegration and destruction. ${ }^{24}$ Such actions are manifestations of the universal

\footnotetext{
${ }^{13}$ Fadlallah 1985: 124.

${ }^{14}$ Fadlallah 1985: 116.

${ }^{15}$ Fadlallah 1985: 136.

${ }^{16}$ FadLallah 1985: 124.

${ }^{17}$ Fadlallah 1985: 125-127.

${ }^{18}$ Fadlallah 1985: 132-134.

${ }^{19}$ Fadlallah 1985: 132-134.

${ }^{20}$ Fadlallah 1985: 142.

${ }^{21}$ Fadlallah 1985: 196.

${ }^{22}$ Fadlallah 1985: 170.

${ }^{23}$ Fadlallah 1985: 143.

${ }^{24}$ FadLaLLah 1985: 117-118.
} 
responsibility that each Muslim should bear. ${ }^{25}$ Practical involvement in social affairs can take many forms such as financial help, social awareness, forgiving and compassion, and fulfilling the obligation of "commanding right and forbidding wrong". ${ }^{26}$ Fadlallah states that the refusal of a duty - abstaining from action - equals unbelief and both count as deviation. $^{27}$

Fadlallah believed that the distinct spirit of Islam is embodied in the traditions and institutions of the Muslim society, first of all in the form of solidarity among its members. The Qur'anic statement that "believers are but brothers" (49:10) implies a spontaneous, practical responsibility for one another by the members of the community. ${ }^{28}$ Solidarity as a factor of social cohesion is a legal obligation, and falls under the scope of individual responsibility for the common goals of the community. ${ }^{29}$

Fadlallah claims that social solidarity is more important than the accomplishment of certain rituals. ${ }^{30} \mathrm{He}$ rejects that there is such a thing in Islam as individual salvation - and claims that spirituality offers no salvation unless it is achieved within a society. ${ }^{31}$ He argues that law, ethics and society are so interrelated in Islam that no legislation that concerns the individual is devoid of social meaning, and a person's evaluation is based on his social manners. Fadlallah pushes this argument to the extreme when he declares that in Islamic law the individual, as such, does not exist separated from society. ${ }^{32}$

\subsection{ORGANIC UNITY}

Fadlallah compares social cohesion to the organising principle of a human body. He asserts that

[t]he social and collective life of Muslims is an organic unity [...] This suggests to man that he does not represent an independent entity, rather a part of an integrated whole. $^{33}$

This concept assumes that society is a dynamic, continuously changing unit that functions by responding to inner and outer influences. Consequently, social processes are made up of the web of human interactions. Individuals are mutually dependent, and there is no tension between the interest of the community and that of its members. The base principles of the community are embodied in all social phenomena and movement. Individuals can function only as components of a society; their existence gains its deep meaning through their contribution to the common goals.

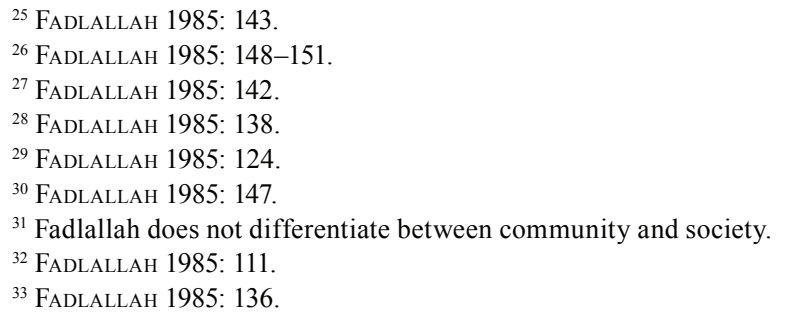


For Fadlallah, what distinguishes the Islamic society from other contemporary or past formations is that those have been founded on tribal bonds, race or ethnicity; while in Islam bonds are based on the commitment to the revealed truth. ${ }^{34}$ In his view, shared visions on nature and society are indispensible for a community. The destruction of a normative order annihilates the morality built upon it and thus leads to chaos. Therefore it is a collective interest to preserve and protect or to restore the ideological foundations of a common value system. ${ }^{35}$

Regarding the needs of the individual, Fadlallah insists that Islam promotes a balanced stance between rigour and profaneness. Man has the right to satisfy his natural needs but he has to set limits for himself to prevent his desires become destructive. Religious regulations serve to assure integrity and equilibrium at the individual as well as at the social level. This way neither side is weakened or strengthened at the expense of the other. It is "a give and take process" that creates balance among the various constituents of the society.

\subsection{FADLALLAH'S FUNCTIONALIST APPROACH TO SOCIAL STRENGTH}

As it is to be proved in the following paragraphs, Fadlallah's model of the strong society reflects Durkheim's approach in many instances. In both paradigms, society is an organic unity whose constituents are mutually dependent members. These individuals are neither independent nor isolated; they have a specific function in the operation and maintenance of the system. The unity of the society is based on the equilibrium of its parts to which organic solidarity is essential. Society as a living organism is responsive to internal changes and external influences. Certain inputs may divert the predominant values of the society from justice, fairness and equity. Thus they cause loss of balance that challenges the stability of the system, and result in its dysfunction.

For Fadlallah, social cohesion as the major source of social strength is based on individual faith, the individual responsibility of fulfilling the legal commitments, and the common goals of the community. ${ }^{36}$ Society as a whole has a function in the context of the revelation: to implement divine justice on Earth. In his thought the individual and social aspects of the Islamist system are interrelated and consecutive. The state of disequilibrium occurs when the predominant values of the society diverge from the Islamic principles; that is practice becomes detached from theory.

Functionalism considers the system as "homeostatic" or self-regulating, and thus able to restore the equilibrium or level negative influences in order to secure the stability of the establishment. ${ }^{37}$ However, the self-regulating mechanism of a social system cannot operate without the various manifestations of force. Thus force and law are functional in controlling the system and assuring the effectiveness of its parts. In Fadlallah's theory, force and primarily the "force of law" is essential in maintaining the equilibrium of the Islamic

\footnotetext{
${ }^{34}$ Fadlallah 1985: 118.

${ }^{35}$ Fadlallah 1985: 122.

${ }^{36}$ Fadlallah 1985: 124.

${ }^{37}$ Conteh-Morgan 2007: 51.
} 
social order. Fadlallah defines shari' $a$ as "laws [that] point [...] in the right direction and $[\ldots]$ show $[. .$.$] how to take steps to avoid any elements that might weaken society" { }^{38}$ In this sense the elements of the Islamic law are comparable to "social facts" in Durkheim's definition. For Durkheim, social facts have an independent existence greater and more objective than individuals' perceptions. Furthermore, a social fact cannot be explained except by another social fact.$^{39}$ In Islam - and thus for Fadlallah - the principles of Islamic law are ordained by God. The elements of Islamic law are instrumental to the realization of just society. Consequently, Fadlallah argues that "[i]t is the logical path towards social cohesion [...] to [put] Islamic laws into practice". ${ }^{40}$

The biggest challenge to social equilibrium appears in the form of individual inclinations and aspirations. For Durkheim, disorder results from the inappropriate function of "solidarity-producing social process[es]", the most important of which is interaction between members of the society. ${ }^{41}$ Thus force in its various forms from regulation to punishment is indispensible for the individual and consequently for the social equilibrium.

\section{COMMANDING RIGHT}

The last feature of a strong society is "commanding right and forbidding wrong". It is a religious and political, communal and individual responsibility, and the success of its fulfilment presupposes individual awareness as well as social organization. Solidarity as a comprehensive, practical attitude, a manifestation of divine mercy towards Man, ${ }^{42}$ is also a legal obligation. ${ }^{43}$ It creates social unity and integrity and consequently cohesion and strength. Therefore the attributes of solidarity and compassion fall under the scope of "commanding right and forbidding wrong". Society, as a whole, is able to assume this function only if its members fulfil their individual duties. ${ }^{44}$ In Fadlallah's view, individual inclinations and aspirations constitute a centrifugal force that can endanger solidarity and justice, and as such need to be controlled. Therefore social justice and cohesion is inherently linked to the obligation of commanding right and forbidding wrong. It serves to regulate and unify the society, to build the base for a strong community, and to protect it against the individual tendencies that could result in its destruction.

Fadlallah defines "commanding right and forbidding wrong" as the basis of Islamic obligations. It prompts the fulfilling of religious duties, and affects all branches of legislation. As a social and political organizing principle it compels the rulers as well as the ruled to establish and maintain justice, order and security. For Fadlallah, it is a "kind of solidarity" that is binding on all Muslims, as an indication of the personal responsibility for the community. ${ }^{45}$

\footnotetext{
${ }^{38}$ Fadlallah 1985: 124.

${ }^{39}$ Durkheim 1982: 162.

${ }^{40}$ Fadlallah 1985: 124. See also: Chapter 4 on social power.

${ }^{41}$ Pope 1975: 364.

${ }^{42}$ See also: "divine mercy is manifested in (includes) human interactions," 115.

${ }^{43}$ Fadlallah 1985: 144.

${ }^{44}$ Fadlallah 1985: 152.

${ }^{45}$ Fadlallah 1985: 151.
} 
Since the consequences of doing wrong will not be limited to those who committed the wrongdoing, personal freedom cannot be devoid of social responsibility. Fadlallah argues that Man is free in his own issues but not in those that affect the society. ${ }^{46}$ Therefore "Islam does not believe in absolute freedom only if subordinated to the requirements of the message and the society". ${ }^{47} \mathrm{He}$ considers this a solution that harmonizes and unites the freedom of the individual and that of the community.

Fadlallah states that the obligation of "commanding right and forbidding wrong" sets the perspective for human social awareness. If deviation is not confronted, the measure of action is lost. ${ }^{48}$ By wrong Fadlallah means corruption and deviation from religious norms. On a social level, it can take the form of despotism, aggression, deprivation of rights, mistreatment, harm, injustice or oppression. For him, forbidding includes armed resistance or - if the conditions are not guaranteed - boycott and exodus. ${ }^{49}$ Conversely, good serves the best interests of human beings, in both public and private life. As for the Muslim community, those who do not comply with this duty deserve to be outcast. ${ }^{50}$ Neglecting the duty of "duty commanding right and forbidding wrong" would only lead to the destruction of faith and justice. ${ }^{51}$ For Fadlallah evil does not occur by God's decree; rather it is a natural effect of human action or neglect.

In the sphere of practice, Fadlallah evokes the individual's responsibility to be alert and eradicate any form of deviation or corruption one experiences in daily life. Social decline is the natural consequence of neglecting the duty of "commanding right and forbidding wrong" on a personal as well as on a community level.

\section{FADLALLAH'S STRONG SOCIETY AS A UTOPIA}

For Fadlallah, Islamic society is the perfect social system in which the relationship between the members is that of brotherhood. It should follow the model of the Prophet's city which established a unity of brotherhood between the immigrants from Quraysh' and Muhammad's supporters in Medina. ${ }^{52}$ His description of the first Islamic community is considerably utopian. He sets the community of Medina as a measure of evaluation for contemporary societies without specifying the application of principles in a modern context. Had he not mingled the ideal with the real he would have discovered that the contemporary Muslim society such as the one in Medina according to Durkheim's classification fell into the category of mechanical solidarity. ${ }^{53} \mathrm{He}$ hints at the problem of hypocrites, who lived among the Muslim community, but he does not elaborate on the issue and leaves other well-known internal conflicts without mention. Moreover, he

\footnotetext{
${ }^{46}$ Fadlallah 1985: 157.

${ }^{47}$ Fadlallah 1985: 152.

${ }^{48}$ FadLaLlah 1985: 155.

${ }^{49}$ Fadlallah 1985: 155-156.

${ }^{50}$ FADLALLAH 1985: 152.

${ }^{51}$ Fadlallah 1985: 158.

${ }^{52}$ Fadlallah 1985: 138.

${ }^{53}$ Durkheim 1994: 31-68.
} 
dedicates no attention to the problematic of the collapse of the Muhammadian ideal following his death.

Similarly to his thought on theology and spirituality, where he separates the weak and strong interpretations of Muslim traditions, Fadlallah's imagined society is selective. It carefully borrows elements to Muslim history, erasing Sunni-Shi'i differences and eliding the internal, structural, ideological issues that led to the disunity and fragmentation of Muslim societies. He attempts to derive the base principles operating the imagined community of Medina without providing meticulous analysis a propos their implementation in the variously polarized modern world and especially that of Lebanon.

Also, he skips the questions regarding the connection between leadership and structure, and does not define clearly the scope of individual and communal responsibility. It is particularly conspicuous vis-à-vis the obligation of "commanding right and forbidding wrong". Another problem with Fadlallah's use of this concept is that this base principle is designed to govern an exclusively Muslim community. Without differentiating umma from society - delineated by the borders of the state - as inevitable in the Lebanese context -, Fadlallah's thought loses its realistic grounds. He designs an Islamic social project without studying "whether" and "to what extent" the various elements of this project fit into the very context in which it is articulated.

\section{FADLALLAH'S SOCIAL THOUGHT AND HIZBULLAH'S 1985 OPEN LETTER}

The aforementioned social empowerment of the Shi' $i$ community is best illustrated in the social activism of Hizbullah's that fills the gap in social services where the Lebanese state fails. Islamist movements (e.g. the Muslim Brotherhood and its affiliated organisations in Egypt, Jordan and elsewhere) start competing with the regime at the social level and end at the political one. A close reading of Hizbullah's 1985 Open Letter reveals that it echoes some features of Fadlallah's social thought. Most importantly, it is emphatic about the cohesive force of common goals, and the commitment of the Islamic message to social justice and fighting oppression. Hizbullah's Open Letter not only promotes solidarity with all Muslims in the world, but also extends the call for Muslim-Christian co-operation in forbidding wrong that is to resist oppression and colonial ambitions based on shared values and shared experience. ${ }^{54}$

The Open Letter declares that resistance is an individual as well as communal responsibility. ${ }^{55}$ People are urged to unite for a major goal and get over minor issues - even differences in religion - that cause rifts. ${ }^{56}$ The declaration raises attention to the dangers of fragmentation as serving the divide and rule policy of the oppressive powers. ${ }^{57}$ The manifesto

\footnotetext{
${ }^{54}$ Open Letter 1985. http://archive.youkal.net/index.php?option=com_content\&view=article\&id=451:1985\&catid=34\&Itemid=156, 177 .

${ }^{55}$ Open Letter 181.

${ }^{56}$ Open Letter 177.

${ }^{57}$ Open Letter 184-185.
} 
defines Islam as a strong intellectual and political bond that creates and secures just rule. It insists that capitalism and socialism failed to set the foundations for a just and stable society, or to establish a balance between the individual and the community, between human nature and public interest. ${ }^{58}$ Such criticism reiterates Fadlallah's argument on the interrelatedness of social equilibrium, justice and strength. In the Letter, Hizbullah maintains that Islamic governance must be based on the emotional unity of the members of the community. Fadlallah's influence on the organization has never been admitted on either side; however, it is evident that their analysis of the societal reality shows significant similarities.

Hizbullah's social strategy shows agreements with most values Fadlallah sees as elements of strength. Hizbullah put in place an effective and wide chain of charitable institutions: schools, hospitals, surgeries, orphanages, and diverse social services that employ workers of various denominational background, and are open to serve clients of all faiths even though - following the Lebanese traditions - they are attended mostly by Shi' is. The first such institutions were set up as personal initiatives by Fadlallah from the late 1960s. His primary aim was to provide services to the poor Shi'a, however, since the suburbs of pre-war Beirut were inhabited by religiously mixed population, Fadlallah's institutions were always open to Sunnis, Druze and Christians. He considered social service as a means to create inter- and intra-religious cohesion, and also as the most authentic and peaceful tool of Islamisation. This tradition has been followed by Hizbullah since its official formation and also as a means of its politicization. ${ }^{59}$

\section{CONCLUSION}

The "tale of two societies" - the weak and the strong - Fadlallah tells is a suggestive metaphor. In order to construct the basics of a strong Shi' i community, he reinterpreted social principles of Islam. Fadlallah perceives social reality in dichotomies. His Manichaeism, a characteristic of radical and fundamentalist thinkers, becomes obvious. The principle of his evaluation of the various social and intellectual trends is twofold: whether they support the unity of the Muslim community, and whether they apply the principle of "commanding right and forbidding wrong". For Fadlallah, spirituality does not offer salvation unless it is realized within the social matrix. Individualism is banned from his ideal society.

Fadlallah selected his arguments consciously in order to support the absolute validity of his social system. In this process, he showed no concerns for the suitability of his ideals in a multi-confessional environment like Lebanon. Similarly, he was not preoccupied to offer a realistic picture of the first Muslim community which he vested with attributes such as organic solidarity, a Western sociological term applied to post-industrialised societies.

Nevertheless, Fadlallah's aim was not to measure the prevalent social concepts and to compare them with the Islamic norms following the requirements of a scientific analysis. He had to convince his Shi'i audience - "the despised" of Lebanon (a term applied by

${ }^{58}$ Open Letter 178.

${ }^{59}$ Azani 2011: 116; Alagha 2006: 208; Harik 2004: 104. 
Kramer $)^{60}$ - of the self-sufficiency of the Islamic social formula in terms of its capacity of empowerment. For this, Fadlallah combined elements of Medieval Islamic social thought ("commanding right and forbidding wrong") with Western social concepts (organic unity, solidarity) and interpreted them in an Islamic way, to put forward a project of revitalising the ideal Islamic society in the modern age.

\section{LITERATURE}

AкнAVI, Shahrough

1983: Shariati's Social Thought. In: KedDIE, N.R. (ed.), Religion and Politics in Iran: Shi'ism from Quietism to Revolution. New Haven: Yale University Press, 125-144.

Alatas, S. F.

1999: Islam and Socialism: Perspectives from Autonomous Social Science and Occidentalism. Yearbook of the Sociology of Islam. In: Buchнolt, H. - Stauth, G. (eds), Investigating the South-South Dimension of Modernity and Islam: Circulating Visions, Intellectual Figures, Locations (Vol. 2). Lit-Verlag, Hamburg Transactions Publishers, Rutgers University, 113-129.

AкHAVI, Shahrough

1988: Islam, Politics and Society in the Thought of Ayatullah Khomeini, Ayatullah Taliqani and Ali Shariati. Middle Eastern Studies 24, 404-431.

Alagha, Joseph

2006: The Shifts in Hizbullah's Ideology. Amsterdam University Press, 14, 208.

AzANI, Eitan

2011: Hezbollah: The Story of the Party of God. $2^{\text {nd }}$ ed. Palgrave Macmillan, 116.

CONTEH-Morgan, Earl

2007: Collective Political Violence. Accel Development, 51.

DABLA, Basheer Ahmad

1983: Sociology of Islam: Shariati's Viewpoint. Islamic Culture 57, 277-282.

DurкHEIM, Émile

1994: The Division of Labor in Society. Macmillan, 31-68, 177.

Durкheiм, Émile

1982: Rules of Sociological Method. Free Press, 162.

FADLALLAH, Muhammad Husayn

1985: Islam and the Logic of Power. $3^{\text {rd }}$ ed. Beirut: al-Mu'assasa al-Jam' iya li'l-Dirasat wa al-Nashr.

IBRAHim, Mir Mohammed

1997: A Reconstruction of Social Thought in Islam: A Case Study of Dr. Ali Shariati. Valley Book House.

KRAMER, Martin

1996: The Oracle of Hizbullah. In: AppleBY, R.S. (ed.), Spokesmen for the Despised: Fundamentalist Leaders of the Middle East. University of Chicago Press, 83-181.

PALMER - HariK, Judith

2004: Hezbollah: The Changing Face of Terrorism. London: I. B. Tauris, 82, 104.

Pope, Whitney

1975: Durkheim as a Functionalist. The Sociological Quarterly 16, 361-379.

YADEGARI, Mohammad

1984: Shariati and the Reconstruction of the Social Sciences. American Journal of Islamic Studies 1(1), $53-59$.

Open Letter 1985. http://archive.youkal.net/index.php?option=com_content\&view=article\&id=451:-1985\&catid $=34 \&$ Itemid $=156$

${ }^{60}$ KrAmER 1996: 105, 128. 